\title{
American history resources on the Internet
}

\author{
By Stanley D. Nash, Miles Yoshimura, and William Vincenti
}

\section{America's past finds a bome in cyberspace}

$\mathbf{T}$ he Internet includes a rich variety of resources in American history for librarians, students, and historians, including access to full-text documents, the ability to discover a rich variety of online electronic conferences (listservs), to connect to nearly any electronic library catalog in the world, and to access the emerging number of archival and manuscript catalog sites.

\section{Listservs}

- The H-NET Gopher. The most useful listservs dealing with American history are those associated with H-NET, an organization affiliated with the American Historical Association, which coordinates a large number of history listservs. It maintains a gopher that offers access to book reviews, listserv names and subscription information, conference announcements, grant opportunities, and a variety of documents related to H-NET activities. Access: gopher://h-net.msu.edu/1.

- H-NET Listserv Gophers. Further information on H-NET listservs may be obtained by accessing their individual gophers. The following URL will provide connections to over 40 history listserv gophers. Access: gopher://hnet.msu.edu/11/lists.

- Other listservs. For other lists of historical discussion groups and subscription information, connect to either 1) the Directory of Electronic Conferences: access: gopher://
gopher.usask.ca/00/Computing/Internet $\% 20$ Information/Directory $\% 200 \% \% 20$ Scholarly $\% 20$ Electronic\%20Conferences/History; or 2) Info Magnet: access: http://www.clark.net/pub/ listserv/lshist1.html.

\section{Historical organization homepages and gophers}

These sites are similar to newsletters and are a good way to keep up with the calendar and general activities of a given organization.

- American Antiquarian Society. Access: gopher://mark.mwa.org/1.

- Organization of American Historians. Access: http://www.indiana.edu/ oah/ index.html.

- Cliometric Society (economic history). Access: http://cs.muohio.edu/.

\section{Electronic library catalogs}

- HYTELNET. Access to the electronic library catalogs of most universities is readily available through the software program known as HYTELNET. Access: http://galaxy.einet.net/ hytelnet/START.TXT.html.

- Chicago Center for Research Libraries (CRL). For those affiliated with CRL, which houses a treasure trove of difficult-to-obtain historical materials, connecting to its online cata$\log$ offers historians and librarians the ability to discover an up-to-date listing of its holdings. Access: telnet://128.135.73.2/ (note: logon as guest).

\section{Special collections and archives holdings}

There are an increasing number of archives and

Stanley D. Nash is American and British bistory selector at Rutgers University, e-mail: snasb@gandalf.rutgers.edu; Miles Yoshimura is political science and economics selector at Rutgers, e-mail: yosbimur@gandalf.rutgers.edu; William Vincenti is a reference librarian at Rutgers, e-mail: wgv@rci.nitgers.edu 
repositories that offer electronic access to their holdings and the full text of many finding aids.

- Johns Hopkins University. This site offers connections to some 40 special collections and archives. Access: gopher://musichox.mse. jhu.edu/.

- National Archives (NA). This site serves both as a resource for the NA's extensive archival holdings, as well as a gateway to a number of other archival sites. Access: gopher:/ gopher.nara.gov.

- Repositories of Primary Sources (University of Idaho). Offers a myriad of connections to archives and special collections throughout the globe. Access: http://www.uidaho.edu/ special-collections/Other.Repositories.html.

\section{Full-text access to historical documents}

A growing and potentially useful area emerging on the Internet is that of full-text documents (i.e., official documents, such as treaties, acts etc.). The following sites are currently among the best.

- Documents from the University of Kansas. At this point this connection offers the fullest and best-organized list of U.S. historical documents available via Internet, offering 100+ documents dating from the seventeenth century to 1993. Access: http://history.cc.ukans.edu/ carrie/docs/docs_us.html.

- Documents from the University of Groningen. This site is especially strong in colonial and revolutionary war documents, including such fairly obscure documents as the first, second, and third Virginia colonial charters. Access: http://www.let.rug.nl/ welling/ usa/othertexts.html.

- Treaties via Cornell University. Covering predominantly 1945 on, this site includes such items as the Nuclear Test Ban treaty of 1963 and the recent NAFTA treaty. Access: gopher://gopher.law.cornell.edu/11/foreign.

- Treaties from Wiretap. This commercially owned free service offers many types of text (see also below under General Text Archives). Using the following URL will retrieve a menu that includes a large number of treaty texts from the late 1940s to the early 1990s. Among these are all the Geneva Conventions and a good number of League of Nations agreements. Access: gopher://wiretap.spies.COM/11/ Gov/Treaties.

- Inaugural Addresses of United States Presidents. Via Project Bartleby at Columbia
University you may access the full text of inaugural addresses from Washington through Bush. Access: gopher://gopher.cc.columbia.edu:71/ 11/miscellaneous/cubooks/inaug.

- Presidential Addresses. This connection includes access to annual State of the Union messages from 1789 through 1836. Access: http: //grid.let.rug.nl/ welling/usa/presidents/ addresses.html.

\section{Full-text access to imprints on various subjects}

There are a number of sites which feature access to texts that concentrate on a subject or person. The following are particularly noteworthy archives.

- American Civil War Home Page. This site offers a spectacular and well-organized set of links to diaries, letters, battle descriptions, timelines, bibliographies, military rosters, maps, and graphics related to the Civil War. Access: http://cobweb.utcc.utk.edu/ hoemann/ warweb.html.

- U.S. Civil War Center. Various links to other Internet Civil War sites and books, photographs, bibliographies, and several Civil War newspapers from Louisiana State University. Access: http://www.cwc.lsu.edu/civlink.htm.

- Military History Resources via the University of Kansas. Offers primary sources, articles, some monographs, graphics, bibliographies, book reviews, and links with other sites, covering wars in all periods of American history. Access: http://ukanaix.cc.ukans.edu/history/milhst/m_index.html.

- Native Americans. The University of Kansas also offers connections to historical texts dealing with Native Americans, including "Famous Documents," "Famous Quotes," and the "Great Chiefs." Access: http://kuhttp.cc. ukans,edu/ marc/natlit/natlit.html.

- Anti-Imperialism in the U.S.A., 1898-1935. This Web page includes access to works by John Dewey, Mark Twain, and the Anti-Imperialist League. Access: http:// web.syr.edu/ fjzwick/ail98-35.html.

- New York City History: Lower East Side. Includes access to works by turn-of-thecentury (ca. 1900) observers, including Jacob Riis and William Dean Howells. Access: http:// 140.190.128.190:80/SMC/Dept/history/ Contents.html.

- From Revolution to Reconstruction. An HTML Hypertext survey of American history which contains Hypertext links to appro- 
priate historical documents. Access: http:// grid.let.rug.nl/ welling/usa/revolution.html.

- Marx-Engels Full-Text Library. This site already contains some 38 works, including Capital and the Communist Manifesto. Access: gopher://csf.colorado.edu/11/psn/Marx.

\section{Full-text access to imprints through general text archives}

- Modern English Collection. From the University of Virginia, this enormous list of predominantly literary texts also includes connections to selected writings of historical figures such as Frederick Douglass, W. E. B. Du Bois, Benjamin Franklin, Thomas Jefferson, and Lyndon Johnson. Information is provided on the scanning and the edition used. Beware, if the text has an asterisk it is not accessible to users outside of the university. Access: http:// etext.lib.virginia.edu/modeng.browse.html.

- Texts From Virginia Tech. Mostly literary connections; however, the historical works of famous figures are fairly numerous. Included are works by Benjamin Franklin, Frederick Douglass, Henry David Thoreau and Thomas Jefferson. Access: gopher://gopher.vt.edu: $10010 / 10 / 33$.

- History Connections via the English Server from Carnegie-Mellon. If you click on the words "Up to the English Server," you can access a variety of other texts under categories such as philosophy, which in fact are often historical. Access: http://english-www. hss.cmu.edu/History.html

- Electronic Books from Wiretap. A commercial service offering free access to a sizable number of books and historical documents. The first address listed below will offer access to mostly literary works and a few useful history texts; the second URL connects you to a menu of choices which includes "Vietnam Era Documents" and the "U2 Shootdown Incident of 1960." Access: gopher://wiretap.spies.com/ 11/Books and gopher://wiretap.spies.com/11/ Gov/US-History.

- OBI: Online Book Initiative. Provided by the World Online Service, free of charge, this connection makes available texts ranging from works of Booker T. Washington to documents related to Desert Storm. Access: http:/ ftp.std.com:80/obi/.

- Project Gutenberg. This ambitious project aims at creating an electronic library of thousands of public domain literary texts, and includes a number of useful American his- torical texts such as The Autobiography of Ben Franklin. Access: gopher://fir.cic.net/11/ Gutenberg.

\section{Indexes and guides to historical texts available on the Internet}

Full-text historical monographs are available from a number of sites. The following sites are excellent guides for discovering text sources on the Internet:

- ALEX: A Catalog of Electronic Texts on the Internet. An attempt to locate, index, and permit connections to text material on the Internet. Access: gopher://rsl.ox.ac.uk/11/libcorn/hunter/Browse $\% 20$ Alex/Browse $\% 20$ by $\% 20$ Subject/Browse $\% 20$ by $\% 20$ Subject $\% 3$ a $\% 20$ History.

- University of Kansas: The Virtual Library in History. This site is probably the largest of the growing number of Web sites offering connections to historical sources on the Internet. Access: http://history.cc.ukans.edu/ history/index.html.

- History Computerization Project. Features annotated listings and connections to a huge number of historical sites. Access: http:// www.history.la.ca.us/history.

- Tennessee Tech. More focused than most lists of history connections, especially when seeking text files. Access: gopher:// gopher.tntech.edu/11gopher_root $\% 3 a$ $\% 5$ bcampus.as.hist.edocs $\% 5 \mathrm{~d}$.

- Yahoo. Provides both updated Internet connections to historical sources and connections to several sites that have a strong reputation for listing or indexing historical connections. Access: http://www.yahoo.com/text/ Social_Science/History/American_History/.

- Other useful history gopher sites and homepages. The following sites offer many leads to text sources in American history: Rice University: gopher://riceinfo.rice.edu/11/Subject/History; North Carolina State University: http://www.lib.ncsu.edu/disciplines/025History.html; University of Michigan: gopher:/ /una.hh.lib.umich.edu/11/humanities/history; University of Waterloo: http://www.lib. uwaterloo.ca/discipline/history.

\section{Access to images and sound}

Using Web browsers, such as Mosaic or Netscape, you may access a growing number of sites which transmit images and sound. The following sites are particularly good examples.

(History cont. on page 96) 


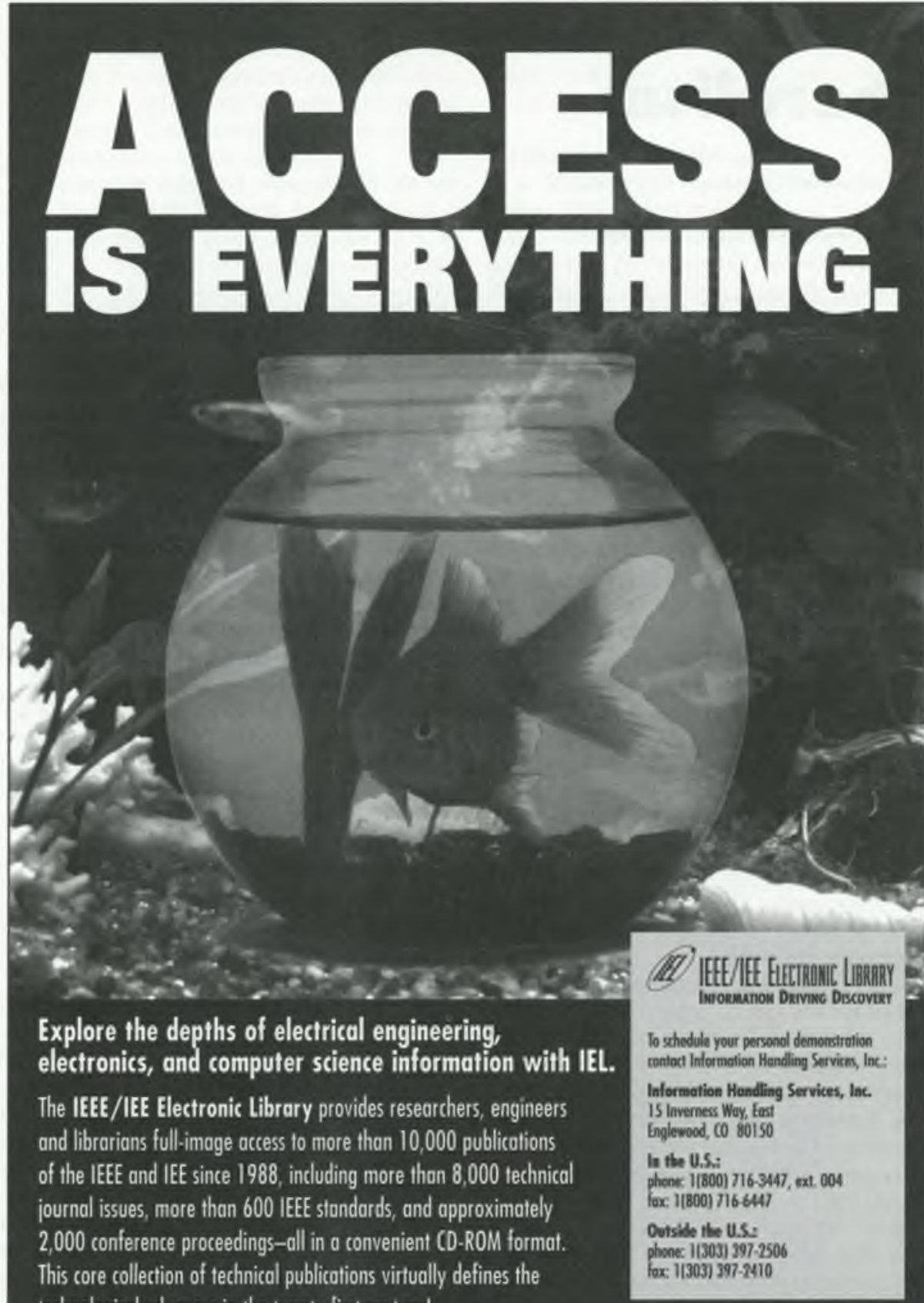
technological advances in the twenty-first century!

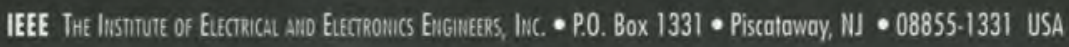




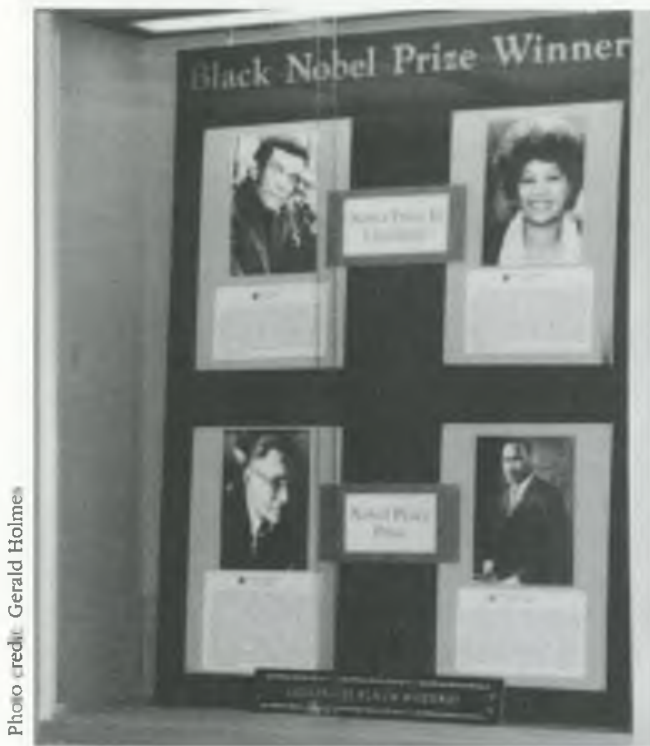

An African American History Month display at Kent State University.

dating to change on a day-to-day basis. From the incoming freshmen to post-doctoral students, African Americans should not be overwhelmed with the vast amount of information that is available to them when enrolling at a new university or college. Librarians should be eager to help these new students become comfortable using the library and its resources to support their entire academic career, and they should provide a strong foundation to prepare students for the future. African American students should not leave the academic environment without being library literate. To prepare for lifelong learning requires that students continue to acquire new skills, pursue career opportunities, enhance their potential for career advancement, and invest time to develop library research skills.

\section{Notes}

1. Alfred Young, "The Historical Origin and Significance of National Afro-American History Month Observance," Negro History Bulletin 43 (1980): 6-8.

2. Charles H. Wesley and Thelma D. Perry, introduction to Carter G. Woodson, The Miseducation of the Negro (1933; reprint, Washington, D.C.: Associated Publishers, 1969).

3. Levirn Hill, "Why We Need More Black Librarians," ABBWA Joumal 4 (1992): 29-30.

4. For information on the kits contact Associated Publishers at (202) 265-1441.

\section{(History cont. from page 84)}

- Civil War Photographs: From the Library of Congress. A selection of important photographs. Access: http://lcweb2.loc.gov/ cwphome.html.

- Rare Maps from the University of Georgia. Colonial, Revolutionary, nineteenthcentury, and many other maps housed at the Special Collections of the University of Georgia are made available to the public. Access: http://scarlett.libs.uga.edu/darchive/hargrett/ maps/maps.html.

- American Memory Project: Library of Congress. This remarkable project makes available documents, speeches and other sound recordings, photographs, and, most impressive, some actual scanned manuscripts. Access: http: //lcweb2.loc.gov/amhome.html.

- American Prohibition Project. Ohio State University's history homepage provides access to photographs and primary text relating to the history of prohibition from its antecedents in the 1870 s through the 1920s. Access: http://www.cohums.ohio-state.edu/history/ projects/prohibition/default.htm.

\section{Electronic journals}

Thus far, electronic journals are not a rich source of information for historians of the U.S. For keeping up with the advent of such journals connect to CICnet. Access: gopher://gopher.cic. net:2000/11/e-serials/archive. Or try the Electronic Journals gopher. Access: gopher://peg. cwis.uci.edu:7000/11/gopher.welcome/peg/ej.

\section{Bibliographies}

An area that promises to be very valuable is that of bibliographies. So far the listservs have been the best source of small reading lists, offered by knowledgeable historians; however, a few lengthy searchable bibliographies are available. The best example is the one on Martin Luther King Jr., from Stanford University, consisting of thousands of sources. Access: telnet://forsythetn.stanford.edu/. Note: When you make the connection type socrates for account, then type yes, and then type select mlk.

Please try our Web page for leads to many other sources. Access: http://www.rutgers.edu/ rulib/artshum/amhist.html. 